\title{
PENGARUH MOTIVASI KERJA, KEPEMIMPINAN TRANSAKSIONAL DAN KEPEMIMPINAN TRANSFORMASIONAL TERHADAP KINERJA KARYAWAN LPP RRI PEKANBARU
}

\author{
Abstract \\ Ilham Chanra Putra, Sartika Yusri \\ Universitas Islam Sultan Syarif Kasim Riau \\ ilham.c.putra@uin-suska.ac.id
}

This research was conducted at Radio Republik Indonesia Pekanbaru which aims to determine the effect of motivation, transactional leadership and transformational leadership on employee performance at Radio Republik Indonesia Pekanbaru. Analysis was conducted on 57 respondents from 130 employees of Radio Republik Indonesia Pekanbaru, sampling was carried out based on the Slovin formula using the simple random sampling method and data collection was carried out with interviews and questionnaires while the data analysis used multiple regression methods with the help of the SPSS Ver program. 21:00. The results of the study concluded that the third (simultaneously) third, namely motivation (X1), transactional leadership (X2) and transformational leadership (X3) significantly influence employee performance (Y). The level of influence of each independent variable on the dependent variable can be determined by conducting a partial test, the results obtained are: motivation variables (X1) affect employee performance (Y), transactional leadership variables (X2) affect employee performance (Y) and leadership transformational (X3) effect on employee performance (Y). And the transactional leadership variable (X2) is a variable whose influence is greater because it has a greater coefficient of determination than the motivational variable (X1). Company leaders should be able to provide motivation to subordinates in both moral and material form to improve employee performance and foster an attitude of loyalty to the company.

Keywords: Motivation, Transactional Leadership, Transformational Leadership, Performance.

\begin{abstract}
Abstrak
Penelitian ini dilaksanakan di Radio Republik Indonesia Pekanbaru yang bertujuan untuk mengetahui pengaruh motivasi, kepemimpinan transaksional dan kepemimpinan transformasional terhadap kinerja karyawan pada Radio Republik Indonesia Pekanbaru. Analisis dilakukan terhadap 57 orang responden dari 130 orang karyawan Radio Republik Indonesia Pekanbaru, pengambilan sampel dilakukan berdasarkan rumus slovin dengan menggunakan metode simple random sampling dan pengumpulan data dilakukan dengan wawancara dan penyebaran kuesioner sedangkan analisis data menggunakan metode regresi berganda dengan bantuan program SPSS Ver. 21.00. Hasil penelitian diperoleh kesimpulan bahwa secara simultan (bersama-sama) ketiga yaitu motivasi $\left(\mathrm{X}_{1}\right)$, kepemimpinan transaksional $\left(\mathrm{X}_{2}\right)$ dan kepemimpinan transformasional $\left(\mathrm{X}_{3}\right)$ berpengaruh secara signifikan terhadap kinerja karyawan (Y). Tingkat pengaruh masing-masing variabel bebas terhadap variabel terikat dapat diketahui dengan melakukan uji parsial, hasil yang diperoleh adalah : variabel motivasi $\left(\mathrm{X}_{1}\right)$ berpengaruh terhadap kinerja karyawan $(\mathrm{Y})$, variabel kepemimpinan transaksional $\left(\mathrm{X}_{2}\right)$ berpengaruh
\end{abstract}


terhadap kinerja karyawan $(\mathrm{Y})$ dan kepemimpinan transformasional $\left(\mathrm{X}_{3}\right)$ berpengaruh terhadap kinerja karyawan (Y). Variabel kepemimpinan transaksional $\left(\mathrm{X}_{2}\right)$ merupakan variabel yang pengaruh lebih besar karena memiliki koefisien determinasi yang lebih besar dibandingkan variabel motivasi $\left(\mathrm{X}_{1}\right)$. Pimpinan perusahaan hendaknya mampu memberikan motivasi kepada para bawahan baik dalam bentuk moril maupun materil untuk meningkatkan kinerja karyawan dan menumbuhkan sikap loyalitas kepada perusahaan.

Kata Kunci : Motivasi, Kepemimpinan Transaksional, Kepemimpinan Transformasional Kinerja.

\section{Pendahuluan}

Organisasi yang baik adalah organisasi yang mampu menempatkan tugas dan wewenang dalam pengelompokkan yang adil dan terukur, sehingga setiap karyawan yang bekerja untuk organisasi tersebut akan mampu menjalankan tugas dengan tanggung jawab sesuai wewenang yang diberikan kepadanya.

Pemberian tugas dan tanggung jawab perlu adanya motivasi yang tepat dari para pimpinan dengan mengamati dan memahami tingkah laku bawahan, dan memperhitungkan, mengawasi dan mengubah serta mengarahkan tingkah laku karyawan. Motivasi terbentuk dari sikap (attitude) seorang pegawai dalam menghadapi situasi (situation) kerja. Sikap mental merupakan kondisi mental yang mendorong diri karyawan untuk berusaha mencapai prestasi kerja secara maksimal.

Dengan demikian motivasi yang diharapkan dari karyawan adalah fungsi dari motivasi dan kemampuan tersebut dapat mempengaruhi kinerja karyawan. Jika terjadi, maka karyawan tersebut harus ditingkatkan kemampuannya dalam bentuk pelatihan dan memberikan penghargaan (incentive).

Salah satu kekuatan yang mampu mendorong peningkatan kinerja karyawan dalam suatu perusahaan atau organisasi adalah Pemimpin/Pimpinan. Kompleksitas masalah yang dihadapi oleh organisasi akan mengakibatkan peningkatan kebutuhan akan kualitas pemimpin organisasi tersebut.

Hal ini disebabkan karena seorang pemimpin merupakan salah satu unsur yang menentukan maju atau mundurnya suatu organisasi. Keberadaan pemimpin merupakan suatu proses dimana seseorang atau pemimpin mempengaruhi bawahannya dengan tanpa paksaan untuk mencapai tujuan organisasi.

Seorang pemimpin yang menggunakan gaya kepemimpinan transaksional membantu karyawannya dalam meningkatkan motivasi untuk mencapai hasil yang diinginkan dengan cara, mengenali apa yang harus dilakukan bawahan untuk mencapai 
hasil yang sudah direncanakan setelah itu pemimpin mengklarifikasi peran bawahannya kemudian bawahan akan merasa percaya diri dalam melaksanakan pekerjaan yang membutuhkan perannya.

Kemudian pemimpin mengklarifikasi bagaimana pemenuhan kebutuhan dari bawahan akan tertukar dengan penetapan peran untuk mencapai hasil yang sudah disepakati. Untuk itu, organisasi memerlukan pemimpin yang reformis yang mampu menjadi motor penggerak perubahan (transformation) organisasi. Dengan kata lain, Kepemimpinan transformasional memotivasi bawahan untuk berbuat lebih baik dari apa yang biasa dilakukan, dengan meningkatkan kepercayaan atau keyakinan diri bawahan.

Berdasarkan pengamatan sementara, gaya kepemimpinan yang diterapkan di Radio Republik Indonesia (RRI) Pekanbaru untuk masa kepemimpinan beberapa waktu lalu masih kurang efektif dilihat dari aspek deskripsi pekerjaan dan spesifikasi pekerjaan. Pimpinan Radio selaku pimpinan yang memiliki hak penuh terhadap kinerja karyawannya, tidak memaksimalkan kinerjanya dalam melaksanakan tugas sebagai pimpinan.

Sebagian karyawan ataupun penyiar masih merasa sungkan untuk menyampaikan ide-ide mereka kepada Kepala Stasiun yang mereka anggap sebagai orang yang tertinggi dalam organisasi dan selalu wajib untuk dihormati, para karyawan dan penyiar selalu menunggu perintah dari Kepala Stasiun Radio. Akan tetapi, terkadang masih ada kesalahpahaman tentang spesifikasi tugas yang diberikan.

Selanjutnya, kinerja karyawan dapat diukur dari tingkat disiplin kerja karyawan. Dari data yang didapat dari penelitian ini, dapat disimpulkan bahwa tingkat absensi karyawan tiap tahunnya mengalami fluktuasi. Adanya penurunan absensi karyawan disebabkan oleh kurang jelasnya kebijakkan mengenai penertiban disiplin dan kurangnya motivasi yang tinggi bagi para karyawan.

Gaya kepemimpinan yang diterapkan Kepala Stasiun kepada para karyawan kurang tegas terutama mengenai kedisiplinan membuat peran pimpinan tersebut dalam meningkatkan kinerja karyawan dinilai belum berhasil secara maksimal.

Hal ini disebabkan oleh adanya hubungan kekeluargaan antara Kepala Stasiun dan juga beberapa orang bawahan yang membuat Kepala Stasiun sulit untuk menindak tegas dan memberi sanksi karyawan yang lalai serta tidak disiplin dalam melaksanakan tugas-tugasnya dikantor. 
Dalam menjalankan tugas masing-masing divisi terdapat fenomena yang menjadi perhatian khusus sebagai berikut :

1. Setiap divisi memiliki keunggulan masing-masing, dimana tingkat penerimaan gaji berbeda, akan tetapi masih banyak karyawan yang tidak tahu menyebabkan adanya kecemburuan sosial.

2. Saat menjalankan tugas ada beberapa peraturan yang tidak diberi arahan oleh atasan, sehingga banyak terjadi masalah dan mengakibatkan tekanan terhadap para karyawan.

3. Jarangnya Kepala Stasiun selaku pimpinan hadir dalam pertemuan antara atasan dan karyawan sehingga komunikasi antara mereka sulit terjalin.

4. Dalam memberikan tugas kepala staf cenderung melupakan arahan yang menjadi motivasi karyawan sehingga timbul kesimpangsiuran tanggung jawab.

5. Karyawan sering melalaikan ketepatan waktu kehadirannya saat menjalankan tugas.

6. Kurang maksimalnya penilaian atasan terhadap karyawan sehingga membuat kesalahpahaman dalam kenaikan jabatan.

Dari hasil fenomena yang muncul diatas, peneliti tertarik untuk melakukan penelitian dengan judul "PENGARUH MOTIVASI KERJA, KEPEMIMPINAN TRANSAKSIONAL DAN KEPEMIMPINAN TRANSFORMASIONAL TERHADAP KINERJA KARYAWAN LEMBAGA PENYIARAN PUBLIK RADIO REPUBLIK INDONESIA PEKANBARU“.

\section{Perumusan Masalah}

Berdasarkan pengamatan yang dilakukan peneliti terhadap latar belakang yang telah disebutkan diatas, maka peneliti merumuskan masalah-masalah yang timbul dalam meningkatkan kinerja karyawan. Adapun perumusan masalah tersebut dapat dilihat dari variabel :

1. Apakah motivasi kerja berpengaruh secara simultan terhadap kinerja karyawan pada Radio Republik Indonesia (RRI) Pekanbaru?

2. Apakah kepemimpinan transaksional berpengaruh secara simultan terhadap kinerja karyawan pada Radio Republik Indonesia (RRI) Pekanbaru?

3. Apakah kepemimpinan transformasional berpengaruh secara simultan terhadap kinerja karyawan pada Radio Republik Indonesia (RRI) Pekanbaru? 
4. Apakah motivasi kerja, kepemimpinan transaksional dan kepemimpinan transformasional secara simultan berpengaruh terhadap kinerja karyawan Radio Republik Indonesia (RRI) Pekanbaru?

\section{Tujuan Penelitian}

Adapun tujuan dari penelitian ini adalah :

1. Untuk mengetahui pengaruh motivasi kerja terhadap kinerja karyawan Radio Republik Indonesia (RRI) Pekanbaru.

2. Untuk mengetahui pengaruh kepemimpinan transaksional terhadap kinerja karyawan Radio Republik Indonesia (RRI) Pekanbaru.

3. Untuk mengetahui pengaruh kepemimpinan transformasinal terhadap kinerja karyawan Radio Republik Indonesia (RRI) Pekanbaru.

4. Untuk mengetahui pengaruh motivasi kerja, kepemimpinan transaksional dan kepemimpinan transformasional terhadap kinerja karyawan Radio Republik Indonesia (RRI) Pekanbaru.

\section{Motivasi Kerja}

Irham Fahmi (2016;71) mendefinisikan motivasi sebagai keadaan kejiwaan dan sikap mental manusia yang memberikan energi, mendorong kegiatan dan menggerakkan dan mengarah atau menyalurkan perilaku kearah mencapai kebutuhan yang memberi kepuasan atau mengurangi ketidakseimbangan. Sedangkan (Nurmansyah;2010;273)mengatakan bahwa motivasi adalah suatu usaha yang dilakukan oleh seorang manajer untuk menggerakan dan menimbulkan semangat kerja bawahan agar bersedia mengambil suatu tindakan yang diperlukan dalam mencapai tujuan organisasi atau perusahaan.

Mathis dan Jackson (2012;312)adalah hasrat didalam diri seseorang menyebabkan orang tersebut melakukan tindakan untuk sesuatu hal dalam mencapai tujuan. Oleh sebab itu, motivasi motivasi merupakan penggerak yang mengarahkan paada tujuan dan itu jarang muncul dengan sia-sia.

\section{Kepemimpinan Transaksional}

George R. Terry yang dikutip oleh (Nurmansyah;2010;263) menyatakan bahwa Kepemimpinan adalah suatu kegiatan untuk mempengaruhi orang agar mau bekerja 
dengan ikhlas untuk mencapai tujuan bersama. Sedangkan (Yulk;2007;27) Kepemimpinan berkaitan dengan proses yang dilakukan oleh seseorang untuk mempengaruhi orang lain, membimbing, membuat struktur, memfasilitasi aktivitas, dan berhubungan dengan suatu kelompok maupun organisasi.

Tyson dan Jacksondalam (Torang;2013;62) memberikan tiga syarat seorang pemimpin yang harus terjadi dalam interaksinya yaitu :

1. Kepemimpinan merupakan suatu konsep relasi (relational concept).

Kepemimpinan hanya ada dalam proses relasi dengan orang lain (para pengikut). Apabila tidak ada pengikut, maka tidak akan ada pemimpin.

2. Kepemimpinan harus merupakan suatu proses.

Otoritas yang diformalkan akan sangat mendorong proses kepemimpinan, namun sekedar menduduki posisi itu tidak menandai seseorang untuk menjadi pemimpin.

3. Kepemimpinan harus membujuk orang lain untuk mengambil tindakan.

Nurmansyah $(2010 ; 96)$ menyatakan bahwa karakteristik yang menjadi acuan didalam kepemimpinan transaksional adalah :

1. Penghargaan bersyarat bila mencapai kinerja yang telah ditetapkan. Kontrak pertukaran dari usaha balas jasa, untuk kinerja yang baik, mengakui pencapaian prestasi.

2. Manajemen dengan pengecualian (aktif)

Mengamati dan mencari penyimpangan dari aturan-aturan dan standar serta melakukan tindakan perbaikan (correction action).

3. Manajemen dengan pengecualian (pasif) Intervensi hanya bila standar tidak terpenuhi atau dilakukan hanya jika standar tidak tercapai.

4. Laissez faire atau bebas kendali. Melepaskan tanggung jawab dan menghindari pengambilan keputusan.

Mamesah et al $(2009 ; 15)$ menyatakan bahwa kepemimpinan transaksional berpengaruh positif dan signifikan terhadap kepuasan kerja karyawan yaitu dimana imbalan yang dikejar oleh dua belah pihak lebih bersifat ekonomi telah tercapai dengan baik dipenuhi oleh pemimpin dan sebagai balasannya pemimpin memperoleh imbalan berupa performa bawahan yang tinggi. 


\section{Kepemimpinan Transformasional}

Robbins dan Coulter (2007;166) menyatakan bahwa kepemimpinan transformasional adalah pemimpin yang memberi inspirasi kepada pengikutnya untuk bertindak melebihi dari kepentingan pribadi mereka demi kebaikan organisasi dan mampu memberikan pengaruh yang dalam dan luar biasa pada pengikutnya. Kepemimpinan transformasional melibatkan suatu proses pertukaran yang dapat menghasilkan suatu kepatuhan dari pengikutnya kepada pemimpin, tetapi tidak mungkin menghasilkan antusiame dan komitmen terhadap sasaran tugas (Yulk;2007;65).

Bass dan Avolio dalam (Nurmansyah;2016;97) menyatakan bahwa ada empat jenis perilaku kepemimpinan transformasional, yaitu :

a. Pengaruh Ideal (idealized influence), yaitu perilaku yang membangkitkan emosi dan identifikasi yang kuat dari pengikutnya kepada pemimpin.

1. Mendapatkan rasa hormat untuk dipercaya.

2. Kepercayaan kepada orang lain.

3. Menampilkan standar moral yang tinggi.

4. Membangun tujuan-tujuan yang menantang bagi pengikutnya.

5. Menjadi model para pengikutnya.

b. Motivasi Inspirasional (inspirational motivation), yaitu meliputi penyampaian visi yang menarik, menggunakan simbol untuk memfokuskan upaya bawahan serta membuat suatu model perilaku yang tepat.

1. Mengacu pada cara pemimpin transformasional dalam memotivasi.

2. Memberi inspirasi yang ada disekitar mereka dengan menyampaikan visi dengan lancar.

3. Percaya diri

4. Meningkatkan optimisme

5. Semangat kelompok

c. Memberikan stimulasi intelektual (intelectual simulation), yaitu perilaku yang meningkatkan kesadaran pengikut akan suatu permasalahan dan mempengaruhi pengikut untuk memandang masalah dari perspektif yang baru.

1. Membuat kembali kerangka permasalahan.

2. Menunjukkan usaha pemimpin yang mendorong pengikut menjadi inovatif. 
d. Pertimbangan Individual (individual consideration), yaitu meliputi pemberian dukungan, dorongan, dan pelatihan bagi pengikut.

1. Memberikan perhatian secara personal pada semua individu

2. Membuat semua individu merasa dihargai

Luthans dalam (Nurmansyah;2016;95) Kepemimpinan transformasional memiliki karakteristik sebagai berikut :

1. Mereka mengidentifikasi dirinya sebagai alat perubahan

2. Mereka berani

3. Mereka mempercayai orang lain

4. Mereka motor penggerak nilai

5. Mereka pembelajar sepanjang masa

6. Mereka memiliki kemampuan menghadapi kompleksitas, ambiguitas, dan ketidakpastian

7. Mereka visioner

\section{Kinerja Karyawan}

Kinerja adalah hasil atau tingkat keberhasilan seseorang secara keseluruhan selama periode tertentu dalam melaksanakan tugas dibandingkan dengan berbagai kemungkinan, seperti standar hasil kerja, target atau sasaran atau kriteria yang telah ditentukan terlebih dahulu telah disepakati bersama (Rivai dan Basri;2005;50)

Pendapat lain mengatakan bahwa kinerja karyawan adalah suatu keadaan yang menunjukkan banyaknya pekerjaan yang harus dilakukan atau dihasilkan seorang individu atau sekelompok kerja sesuai dengan job description mereka masing-masing (Manullang;2006;245). Berdasarkan pendapat diatas dapat disimpulkan bahwa kinerja karyawan adalah hasil kerja yang dicapai seorang karyawan sesuai dengan wewenang atau tanggung jawab masing-masing karyawan selama periode waktu tertentu.

Sedangkan Rivai (2006;309) mengatakan bahwa kinerja merupakan perilaku nyata yang ditampilkan setiap orang sebagai prestasi kerja yang dihasilkan oleh karyawan sesuai dengan perannya dalam perusahaan. Berdasarkan uraian tersebut diatas juga dapat diambil kesimpulan bahwa hasil kerja yang dicapai oleh seorang karyawan dalam melakukan suatu pekerjaan dapat evaluasi tingkat kinerja pegawainya.

Pada umumnya unsur-unsur yang perlu diadakan penilaian dalam proses penilaian kinerja menurut (Hadi Sutrisno;2009;167) sebagai berikut: 
1) Kesetiaan

Kesetiaan yang dimaksud adalah tekad dan kesanggupan untuk mentaati, melaksanakan dan mengamalkan sesuatu yang ditaati dengan penuh kesabaran dan tanggung jawab.

2) Prestasi Kerja

Prestasi kerja adalah kinerja yang dicapai oleh seorang tenaga kerja dalam melaksanakan tugas dan pekerjaan yang diberikan kepadanya.

3) Tanggung Jawab

Tanggung jawab adalah kesanggupan seorang tenaga kerja dalam menyelesaikan tugas dan pekerjaan yang diserahkan kepadanya dengan sebaik-baiknya dan tepat waktu serta berani mengambil resiko atas keputusan yang diambilnya.

4) Ketaatan

Ketaatan adalah kesanggupan seorang tenaga kerja untuk menaati segala ketetapan, peraturan yang berlaku dan menaati perintah kedinasan yang diberikan atasan yang berwenang.

5) Kejujuran

Kejujuran adalah ketulusan hati seorang tenaga kerja dalam melaksanakan tugas dan pekerjaan serta kemampuan untuk tidak menyalahgunakan wewenang yang telah diberikan kepadanya.

6) Kerja Sama

Kerja sama adalah kemampuan tenaga kerja untuk bekerja bersama-sama dengan orang lain dalam menyelesaikan suatu tugas dan pekerjaan yang telah ditetapkan sehingga mencapai daya guna dan hasil guna yang sebesar-besarnya. Keberhasilan atau kegagalan suatu organisasi tergantung pada orang yang terlibat dalam organisasi tersebut.

7) Prakarsa

Prakarsa adalah kemampuan seorang tenaga kerja untuk mengambil keputusan, langkah-langkah atau melaksanakan suatu tindakan yang diperlukan dalam melaksanakan tugas pokok tanpa mengganggu perintah dan bimbingan dari atasan.

8) Kepemimpinan

Kepemimpinan adalah kemampuan seseorang untuk meyakinkan orang lain sehingga dapat dikerahkan secara maksimal untuk melaksanakan tugas pokok. 


\section{Pengaruh Kepemimpinan Transaksional Terhadap Kinerja Karyawan}

Yulk (2007;27) menyatakan bahwa Kepemimpinan berkaitan dengan proses yang dilakukan oleh seseorang untuk mempengaruhi orang lain, membimbing, membuat struktur, memfasilitasi aktivitas, dan berhubungan dengan suatu kelompok maupun organisasi. George R. Terry yang dikutip oleh (Nurmansyah;2010;263) menyatakan bahwa Kepemimpinan adalah suatu kegiatan untuk mempengaruhi orang agar mau bekerja dengan ikhlas untuk mencapai tujuan bersama.

Wayan Gede Supartha (2016) menyatakan bahwa pengaruh gaya kepemimpinan transaksional ( X1 ) terhadap kinerja guru (Y) 0,571. Besarnya pengaruh gaya kepemimpinan transaksional (X1) dan motivasi (X2) berpengaruh secara bersamasama sebesar 73,5 persen sementara sisanya 26,5 persen dijelaskan oleh variabel lain.

Katim dan Cucu Wiliyati (2016) menyatakan bahwa Gaya kepemimpinan transaksional terbukti tidak berpengaruh terhadap kinerja, dan sebagai tambahan, model simultan juga memberikan kesimpulan bahwa tidak ada pengaruh simultan kepemimpinan traksaksional dan motivasi terhadap kinerja di Hotel Merlyn Park. Vanni Andistia Italiani (2013) berdasarkan hasil penelitian menyimpulkan gaya kepemimpinan transaksional berpengaruh terhadap kinerja karyawan.

Berdasarkan hasil dari penelitian terdahulu yang telah dijabarkan diatas, maka diperoleh hasil bahwa kepemimpinan transaksional berpengaruh terhadap kinerja karyawan.

\section{Pengaruh Kepemimpinan Transformasional Terhadap Kinerja Karyawan}

Tjutju Yunarsih dan Suwanto $(2009 ; 165)$ menyatakan bahwa Kepemimpinan transformasional merupakan pengaruh antar pribadi yang dilaksanakan dalam situasi dan arahan, melalui proses, komunikasi, menuju pencapaian tujuan yang spesifik dalam kinerjanya.

Seorang pemimpin harus menerapkan gaya kepemimpinan untuk mengelola bawahannya, karena seorang pemimpin akan sangat mempengaruhi keberhasilan kinerja dalam mencapai tujuannya (Waridin dan Guritno;2005:49). Dimana para karyawan merasa percaya, mengagumi, loyal dan menghormati pemimpin, serta memiliki motivasi yang tinggi untuk berprestasi dan berkinerja tinggi (Mc Kenne dan Nic Beech;2010;122) 
Putri Novitasari dan Budhi Satriyo (2016) menyatakan bahwa kepemimpinan transformasional berpengaruh terhadap kinerja karyawan di Sekolah Tinggi Ilmu Ekonomi Indonesia (STIEI) Surabaya.

Katim dan Cucu Wiliyati (2016) menyatakan bahwa kepemimpinan transformasional berpengaruh terhadap kinerja karyawan di Hotel Merlynn Park. Wayan Gede Supartha (2016) menyatakan bahwa pengaruh gaya kepemimpinan transformasional berpengaruh simultan terhadap kinerja karyawan di SMU N 02 Baucau Timor Leste.

Berdasarkan hasil dari penelitian terdahulu yang telah dijabarkan diatas, maka diperoleh hasil bahwa kepemimpinan transformasionall berpengaruh signifikan simultan terhadap kinerja karyawan.

\section{Pengaruh Motivasi Kerja, Kepemimpinan Transaksional dan Kepemimpinan Transformasional Terhadap Kinerja Karyawan}

Dalam konteks pekerjaan, motivasi merupakan salah satu faktor penting dalam mendorong seorang karyawan untuk bekerja. Motivasi adalah suatu kondisi yang berpengaruh untuk membangkitkan, mengarahkan dan memelihara perilaku yang berhubungan dengan lingkungan kerja. Bila seseorang termotivasi maka ia akan berupaya sekuat tenaga untuk mencapai tujuan, namun belum tentu upaya yang tinggi akan menghasilkan kinerja yang tinggi (Sudiyarto dan Waskito;2006;27).

Oleh karena itu, diperlukan intensitas dan kualitas dari upaya tersebut serta difokuskan pada tujuan organisasi. Seorang pemimpin juga harus mampu melihat dan memahami orang yang berada dibawah kepemimpinannya, dengan menggunakan pengetahuannya tentang hubungan kemanusiaan dalam kelompoknya. Seorang pemimpin akan dapat melihat gambaran tentang motif-motif seseorang untuk lebih giat lagi melaksanakan tugasnya. Kegiatan memberikan motivasi tersebut tidak akan berhasil apabila pemimpin tidak memiliki cara-cara tertentu untuk melaksanakannya.

Tingkat sejauh mana seorang pemimpin disebut transaksional dan transformasional terutama diukur dalam hubungannya dengan efek pemimpin tersebut terhadap para pengikut. Kepemimpinan transformasional lebih meningkatkan motivasi dan kinerja pengikut dibandingkan dengan kepemimpinan transaksional (Soekarini;2014;12). 
Putri Novitasari dan Budhi Satriyo (2016) menyatakan bahwa gaya kepemimpinan transformasional dan motivasi berpengaruh terhadap kinerja karyawan di Sekolah Tinggi Ilmu Ekonomi Indonesia (STIEI) Surabaya.

Katim dan Cucu Wiliyati (2016) menyatakan bahwa gaya kepemimpinan transaksional dan motivasi berpengaruh terhadap kinerja karyawan di Hotel Merlynn Park.

Wayan Gede Supartha (2016) menyatakan bahwa pengaruh gaya kepemimpinan dan motivasi berpengaruh simultan terhadap kinerja karyawan di SMU N 02 Baucau Timor Leste.

\section{Kerangka Pemikiran}

\section{Kerangka Pemikiran}

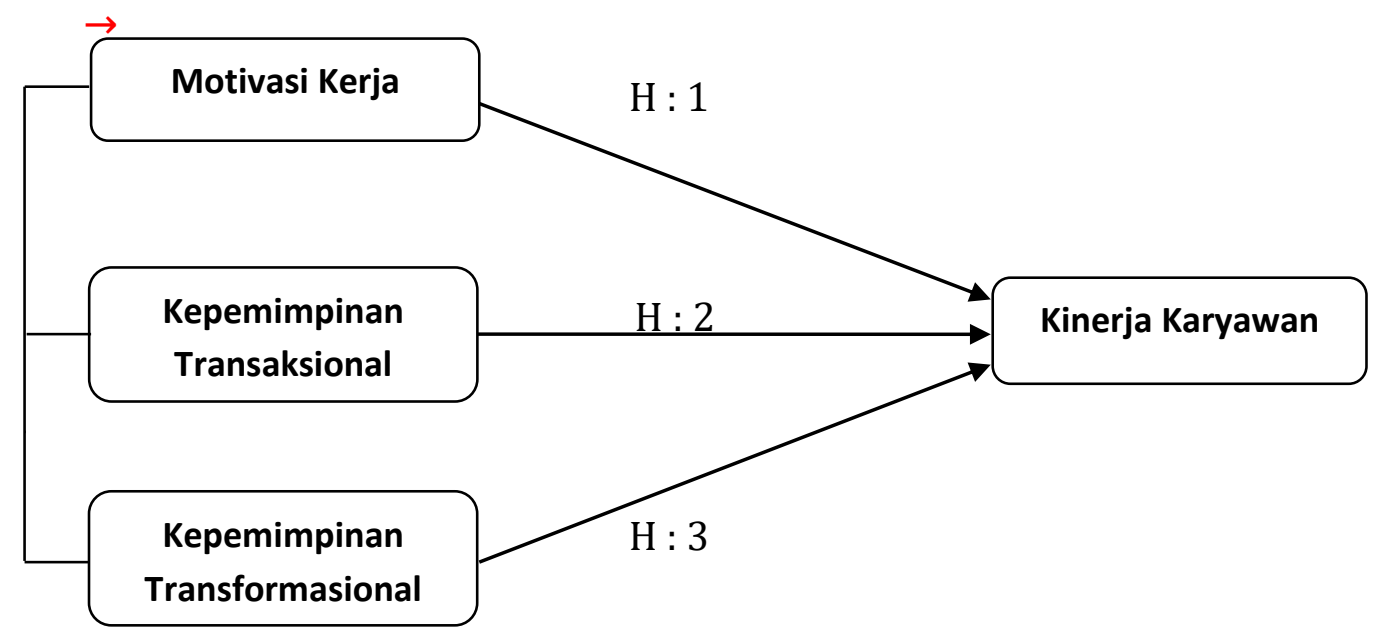

\section{Hipotesis}

Berdasarkan perumusan masalah yang telah dikemukakan, dapat dirumuskan hipotesis dalam penelitian adalah :

1. Terdapat pengaruh yang signifikan dari motivasi $\left(\mathrm{X}_{1}\right)$ secara simultan terhadap kinerja (Y) karyawan LPP Radio Republik Indonesia (RRI) Pekanbaru.

2. Terdapat pengaruh yang signifikan dari Kepemimpinan transaksional ( $\left.\mathrm{X}_{2}\right)$ secara simultan terhadap kinerja (Y) karyawan LPP Radio Republik Indonesia (RRI) Pekanbaru.

3. Terdapat pengaruh yang signifikan dari Kepemimpinan Transformasional $\left(\mathrm{X}_{3}\right)$ secara simultan terhadap kinerja (Y) karyawan LPP Radio Republik Indonesia (RRI) Pekanbaru. 
4. Terdapat pengaruh Motivasi kerja $\left(\mathrm{X}_{1}\right)$, Kepemimpinan Transaksional $\left(\mathrm{X}_{2}\right)$, Kepemimpinan Transformasional $\left(\mathrm{X}_{3}\right)$ secara simultan terhadap kinerja ( $\mathrm{Y}$ ) karyawan LPP Radio Republik Indonesia (RRI) Pekanbaru.

\section{Metodologi Penelitian}

\section{Objek Penelitian}

Peneliti melakukan penelitian terhadap Motivasi Kerja, Kepemimpinan Transaksional dan Kepemimpinan Transformasional Terhadap Kinerja karyawan pada Stasiun Radio Republik Indonesia Pekanbaru yang beralamat di Jalan Jenderal Sudirman No. 440 Pekanbaru.

\section{Populasi dan Sampel}

Populasi dalam penelitian ini adalah seluruh karyawan Radio Republik Indonesia Pekanbaru 2019 yang berjumlah 130 karyawan. Dari populasi sebanyak 130 karyawan maka penulis hanya mengambil sampel dari populasi yang ada sebanyak 57 karyawan.

\section{Teknik Pengambilan Sampel}

Metode pengumpulan data melalui kuesioner dan wawancara langsung pada seluruh karyawan Jamkrindo Kantor Cabang Pekanbaru tentang berbagai informasi/data yang diperlukan dengan menggunakan skala likert.

Skala likert digunakan untuk mengukur sikap, pendapat dan persepsi seseorang atau sekelompok orang tentang fenomenal sosial. Dengan skala likert, maka variabel yang diukur dan dijabarkan menjadi indikator variabel.

Sebagai titik tolak untuk menyusun item - item instrument yang dapat berupa pernyataan dan pertanyaan. Jawaban setiap item yang menggunakan skala likert mempunyai gradiasi dan sangat positif sampai sangat negatif (Sugiyono, 2011).

Kemudian untuk mengetahui rata - rata jawaban responden digunakan interval kelas, interval kelas dapat dirumuskan dengan rumus :

Adapun skala yang digunakan adalah sebagai berikut ini :

$\begin{array}{lccc}\text { 1.Sangat Setuju } & \text { skor } & 5 & \text { dengan range }(4,21-5,00) \\ \text { 2.Setuju } & \text { skor } & 4 & \text { dengan range }(3,41-4,20) \\ \text { 3. Netral } & \text { skor } & 3 & \text { dengan range }(2,61-3,40) \\ \text { 4. Tidak Setuju } & \text { skor } & 2 & \text { dengan range }(1,81-2,60) \\ \text { 5. Sangat Tidak Setuju } & \text { skor } & 1 & \text { dengan range }(1,00-1,80)\end{array}$




\section{Identifikasi Dan Operasionalisasi Variabel}

\begin{tabular}{|c|c|c|c|}
\hline No. & Variabel & Indikator & Skala \\
\hline 1. & $\begin{array}{l}\text { Motivasi kerja }\left(\mathrm{X}_{1}\right) \text { adalah } \\
\text { proses pemberian dorongan } \\
\text { kepada bawahan supaya } \\
\text { bawahan dapat bekerja } \\
\text { sejalan dengan batasan } \\
\text { yang diberikan guna } \\
\text { mencapai tujuan organisasi } \\
\text { secara maksimal. } \\
\text { (Robbins;2006;5) }\end{array}$ & $\begin{array}{l}\text { 1. Pemenuhan kebutuhan } \\
\text { fiologis } \\
\text { 2. Pemenuhan kebutuhan } \\
\text { rasa aman } \\
\text { 3. Pemenuhan kebutuhan } \\
\text { sosial } \\
\text { 4. Pemenuhan kebutuhan } \\
\text { penghargaan } \\
\text { 5. Pemenuhan kebutuhan } \\
\text { aktualisasi diri } \\
\text { (Robbins;2006;55) }\end{array}$ & Ordinal \\
\hline 2. & $\begin{array}{l}\text { Kepemimpinan } \\
\text { Transaksional }\left(\mathrm{X}_{2}\right) \text { adalah } \\
\text { pemimpin } \\
\text { membimbing } \\
\text { memotivasi pengikutnya } \\
\text { menuju ke sasaran yang } \\
\text { telah ditetapkan dengan } \\
\text { memperjelas peran dan } \\
\text { persyaratan tugas } \\
\text { (Nurmansyah;2016;97) }\end{array}$ & $\begin{array}{l}\text { 1. Kejelasan tugas pada } \\
\text { karyawan } \\
\text { 2. Mematuhi aturan dan } \\
\text { standar kerja } \\
\text { 3. Mengatur kesepakatan } \\
\text { kontraktual } \\
\text { 4. Pengawasan dalam } \\
\text { pekerjaan } \\
\text { 5. Memberikan } \\
\text { penghargaan dalam } \\
\text { memotivasi karyawan } \\
\text { (Djamaludin;2012;128) }\end{array}$ & Ordinal \\
\hline 3. & $\begin{array}{l}\text { Kepemimpinan } \\
\text { Transformasional } \\
\text { adalah kepemimpinan yang } \\
\text { membutuhkan tindakan } \\
\text { memotivasi para bawahan } \\
\text { agar bersedia bekerja demi }\end{array}$ & $\begin{array}{l}\text { 1. Kebanggaan } \\
\text { 2. Rasa Hormat } \\
\text { 3. Memotivasi bawahan } \\
\text { 4. Kemampuan } \\
\text { 5. Perhatian } \\
\text { 6. Penghargaan }\end{array}$ & Ordinal \\
\hline
\end{tabular}




\begin{tabular}{|c|c|c|c|}
\hline & $\begin{array}{l}\text { sasaran-sasaran "tingkat } \\
\text { tinggi" yang dianggap } \\
\text { melampaui kepentingan } \\
\text { pribadinya pada saat itu. } \\
\text { (Sri Utami;2006) }\end{array}$ & (Sri Utami;2006) & \\
\hline 4. & 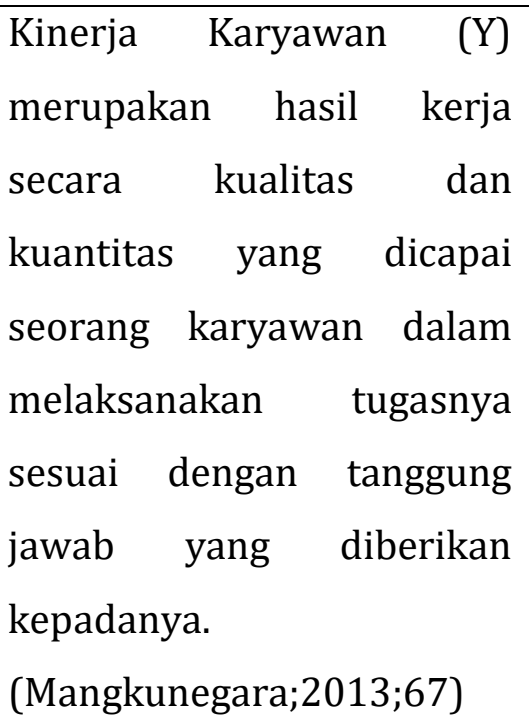 & $\begin{array}{l}\text { 1. Kualitas } \\
\text { 2. Kuantitas } \\
\text { 3. Waktu } \\
\text { 4. Disiplin } \\
\text { 5. Kepemimpinan } \\
\text { PPRI Nomor } 46 \text { Thn } 2011\end{array}$ & Ordinal \\
\hline
\end{tabular}

\section{Hasil Penelitian dan Pembahasan}

\section{Analisis Regresi Linier Berganda}

Persamaan regresi berganda digunakan untuk menggambarkan model hubungan antar variabel bebas dengan variabel terikatnya. Persamaan regresi ini memuat nilai konstanta atau intercept nilai koefisien regresi atau slope dan variabel bebasnya. Berdasarkan hasil penelitian, persamaan dalam analisis regresi linier berganda dalam penelitian ini adalah :

\section{Rekapitulasi Hasil Output Uji Regresi Linier Berganda}

\begin{tabular}{|l|c|c|c|c|}
\hline & & Standardi & & \\
zed & & & \\
Model & Unstandardized & Coefficien & & \\
Coefficients & $\mathrm{ts}$ & $\mathrm{t}$ & Sig. \\
\hline
\end{tabular}




\begin{tabular}{|c|c|c|c|c|c|c|}
\hline & & B & $\begin{array}{l}\text { Std. } \\
\text { Error }\end{array}$ & Beta & & \\
\hline \multirow[t]{4}{*}{1} & (Constant) & 4.931 & 1.811 & & 2.723 & .009 \\
\hline & Motivasi (X1) & .232 & .111 & .198 & 2.082 & .042 \\
\hline & Transaksional (X2) & .413 & .089 & .412 & 4.652 & .000 \\
\hline & $\begin{array}{l}\text { Transformasional } \\
\text { (X3) }\end{array}$ & .400 & .109 & .387 & 3.670 & .001 \\
\hline
\end{tabular}

a. Dependent Variable: Kinerja (Y)

Berdasarkan tabel diatas dapat diperoleh persamaan regresi linear berganda sebagai berikut :

$$
Y=4.931+0,232 X_{1}+0,413 X_{2}-0,400 X_{3}
$$

Adapun interpretasi dari persamaan regresi di atas adalah sebagai berikut:

a) Nilai Konstanta sebesar 4.931 menunjukkan variabel independen yaitu motivasi, kepemimpinan transaksional dan kepemimpinan transformasional dianggap konstan (bernilai 0), nilai variabel dependen yaitu kinerja karyawan adalah sebesar 4.931.

b) Nilai Koefisien motivasi ( $\left.\mathrm{X}_{1}\right)$ terhadap kinerja $(\mathrm{Y})$ adalah, Koefisien regresi variabel motivasi sebesar 0,232 menunjukkan motivasi meningkat maka kinerja meningkat pula sebesar 0,232 atau 23,2 \%. Koefisien bernilai positif hal ini berarti semakin meningkat motivasi maka semakin meningkat pula kinerja, begitu juga sebaliknya.

c) Nilai Koefisien kepemimpinan transaksional $\left(\mathrm{X}_{2}\right)$ terhadap kinerja(Y) adalah, Koefisien regresi variabel kepemimpinan sebesar 0,413 bahwa kepemimpinan meingkat maka kinerja karyawan akan meningkat sebesar 0,413 atau 4,13 \%. Koefisien bernilai positif hal ini berarti semakin meningkat nilai kepemimpinan transaksional maka semakin meningkat pula kinerja pada karyawan,begitu juga sebaliknya.

d) Nilai Koefisien kepemimpinan transformasional ( $\left.\mathrm{X}_{3}\right)$ terhadap kinerja karyawan(Y), Koefisien regresi variabel kepemimpinan transformasional sebesar 0,400 menunjukkan bahwa kepemimpinan transformasional meningkat maka 
kinerja karyawan akan meingkat sebesar 0,400atau $40 \%$. Koefisien bernilai positif maka semakin meningkat pula kinerja karyawan, begitu juga sebaliknya.

\section{Analisis Regresi Simultan / Uji “ F“}

\section{Tabel Rekapitulasi Hasil Output Uji F}

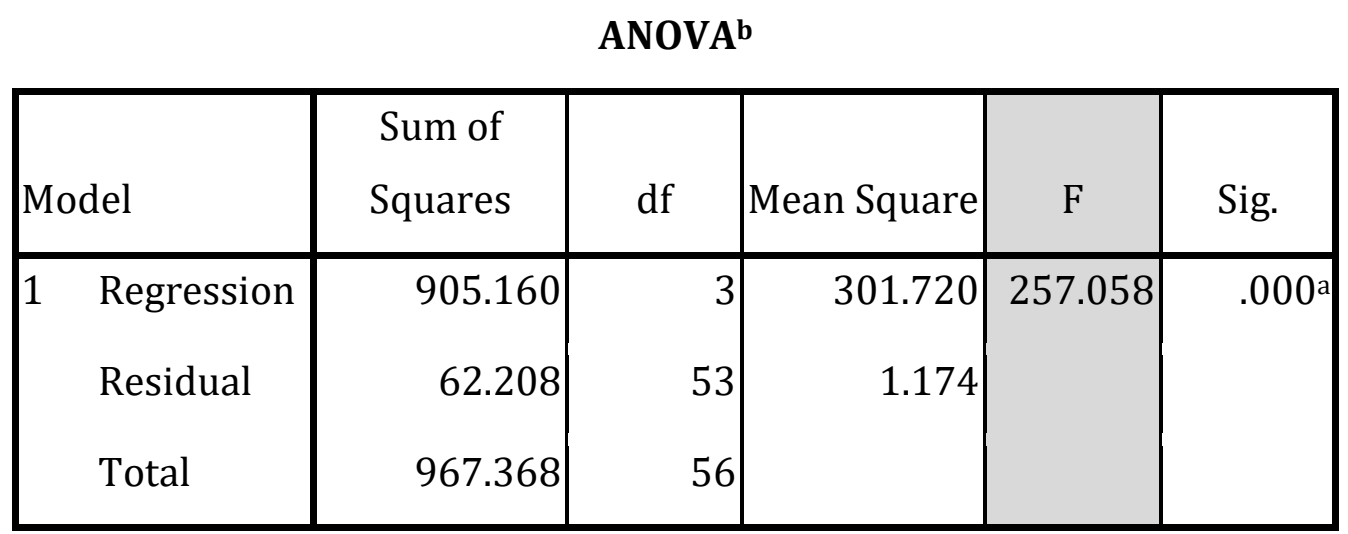

a. Predictors: (Constant), Transformasional, Transaksional, Motivasi

b. Dependent Variable: Kinerja

Dalam pengujian ini penulis merumuskan hipotesis statistik sebagai berikut :

$\mathrm{H}_{0}$ : Tidak adanya pengaruh yang signifikan dari motivasi, kepemimpinan transaksional dan kepemimpinan transformasional secara bersama-sama terhadap kinerja.

$\mathrm{H}_{1} \quad$ : Adanya pengaruh yang signifikan dari motivasi, kepemimpinan transaksional dan kepemimpinan transformasional secara bersama-sama terhadap kinerja. Kriteria yang digunakan adalah apabila nilai $\mathrm{F}_{\text {hitung }}>\mathrm{F}_{\text {tabel, }}$ maka $\mathrm{H}_{0}$ ditolak dan $\mathrm{H}_{1}$ diterima.

Artinya ada pengaruh yang signifikan dari variabel bebas secara bersama-sama terhadap variabel terikat. Apabila nilai $F_{\text {hitung }}<\mathrm{F}_{\text {tabel, }}$, berarti kedua variabel tersebut tidak berpengaruh secara signifikan terhadap variabel tersebut.

Berdasarkan hasil perhitungan Tabel 5.49 diperoleh nilai F sebesar 257.058. Jika dilihat dari nilai Fhitung $>F_{\text {tabel }}(2,78)$ Persamaan regresi dapat dinyatakan signifikan yang berarti bahwa secara bersama motivasi, kepemimpinan transaksional dan kepemimpinan transformasional berpengaruh terhadap kinerja karyawan. 


\section{Hasil Uji Secara Parsial (Uji T)}

Coefficients $^{\mathbf{a}}$

\begin{tabular}{|c|c|c|c|c|c|}
\hline \multirow[b]{2}{*}{ Model } & \multicolumn{2}{|c|}{$\begin{array}{l}\text { Unstandardized } \\
\text { Coefficients }\end{array}$} & $\begin{array}{l}\text { Standardi } \\
\text { zed } \\
\text { Coefficien } \\
\text { ts }\end{array}$ & & \\
\hline & B & $\begin{array}{l}\text { Std. } \\
\text { Error }\end{array}$ & Beta & $\mathrm{t}$ & Sig. \\
\hline 1 (Constant). & -4.931 & 1.811 & & -2.723 & .009 \\
\hline Motivasi (X1) & .232 & .111 & .198 & 2.082 & .042 \\
\hline Transaksional (X2) & .413 & .089 & .412 & 4.652 & .000 \\
\hline $\begin{array}{l}\text { Transformasional } \\
\text { (X3) }\end{array}$ & .400 & .109 & .387 & 3.670 & .001 \\
\hline
\end{tabular}

a. Dependent Variable: Kinerja (Y)

Berdasarkan tabel diatas maka dapat diketahui sebagai berikut:

1. Pengaruh variabel Motivasi $\left(\mathrm{X}_{1}\right)$ terhadap variabel Kinerja ( $\mathrm{Y}$ ) menunjukan nilai thitung $(2,082)>t_{\text {tabel }}(1,674)$ dengan nilai signifikasi yang dihasilkan sebesar $(0,042)$ berada dibawah 0,05, maka, Ho ditolak dan Hipotesa alternative (Ha) diterima.

2. Pengaruh variabel Kepemimpinan Transaksional $\left(\mathrm{X}_{2}\right)$ terhadap variabel Kinerja (Y) menunjukan nilai thitung $(4,652)>$ tabel $(1,674)$ dengan nilai signifikasi yang dihasilkan sebesar $(0,000)$ berada dibawah 0,05, maka, Ho ditolak dan Hipotesa alternative (Ha) diterima.

3. Pengaruh variabel Kepemimpinan Transformasional $\left(\mathrm{X}_{3}\right)$ terhadap variabel Kinerja (Y) menunjukan nilai thitung $(3,670)>$ tabel $(1,674)$ dengan nilai signifikasi yang dihasilkan sebesar $(0,001)$ berada dibawah 0,05 , maka, Ho ditolak dan Hipotesa alternative (Ha) diterima. 


\section{Koefisien Determinasi $\left(\mathrm{R}^{2}\right)$}

Koefesien determinasi digunakan untuk melihat kemampuan variabel independen dalam menerangkan variabel dependen, dimana nilai $R$ Square yang mendekati satu maka variabel independen memberikan hampir semua informasi yang dibutuhkan untuk memprediksi variasi variabel dependen.

Hasil koefisien determinasi antara kepemimpinan dan promosi jabatan terhadap kinerja dapat dilihat hasilnya pada tabel berikut:

Model Summaryb

\begin{tabular}{|l|r|r|r|r|}
\hline Model & \multicolumn{1}{|c|}{$\mathrm{R}$} & R Square & $\begin{array}{c}\text { Adjusted R } \\
\text { Square }\end{array}$ & $\begin{array}{c}\text { Std. Error of } \\
\text { the Estimate }\end{array}$ \\
\hline 1 & $.967^{\mathrm{a}}$ & .936 & .932 & 1.083 \\
\hline
\end{tabular}

a. Predictors: (Constant), Transformasional, Transaksional, Motivasi

b. Dependent Variable: Kinerja

Dari tabel diatas dapat diketahui Nilai Adjusted $R$ Square $\left(\mathrm{R}^{2}\right)$ sebesar 0,932 atau 93,2\% ini berarti variabel kinerja karyawan dijelaskan oleh nilai kepemimpinan dan promosi jabatan sisanya 6,8\% dipengaruhi oleh variabel lain yang tidak digunakan dalam penelitian ini.

\section{Kesimpulan}

Berdasarkan uraian-uraian yang telah dijelaskan pada bab-bab sebelumnya, maka penulis memperoleh kesimpulan sebagai berikut :

1. Hasil pengujian secara simultan dengan menggunakan uji- F diperoleh hasil bahwa secara bersama-sama kedua variabel bebas yaitu Motivasi ( $\left.\mathrm{X}_{1}\right)$, Kepemimpinan Transaksional $\left(\mathrm{X}_{2}\right)$ dan Kepemimpinan Transformasional $\left(\mathrm{X}_{3}\right)$ berpengaruh signifikan terhadap Kinerja (Y).

2. Tingkat pengaruh masing-masing variabel bebas terhadap variabel terikat dapat diketahui dengan melakukan uji Parsial, hasil yang diperoleh adalah :

a. Variabel motivasi $\left(\mathrm{X}_{1}\right)$ secara parsial berpengaruh terhadap kinerja karyawan karena memiliki thitung $>$ tabel. 
b. Variabel kepemimpinan transaksional $\left(\mathrm{X}_{2}\right)$ berpengaruh signifikan terhadap variabel kinerja karyawan (Y) karena mempunyai thitung $>t_{\text {tabel. }}$

c. Variabel kepemimpinan transformasional $\left(\mathrm{X}_{3}\right)$ berpengaruh signifikan terhadap variabel kinerja karyawan (Y) karena mempunyai $t_{\text {hitung }}>t_{\text {tabel. }}$

d. Variabel kepemimpinan transaksional $\left(\mathrm{X}_{2}\right)$ merupakan variabel yang berpengaruh dominan karena memiliki koefisien regresi yang lebih besar dibandingkan variabel motivasi $\left(\mathrm{X}_{1}\right)$ dan variabel kepemimpinan transformasional $\left(\mathrm{X}_{3}\right)$.

Maka dapat diambil kesimpulan bahwa variabel yang paling berpengaruh terhadap kinerja pada karyawan Radio Republik Indonesia Pekanbaru adalah variabel Kepemimpinan Transaksional.

\section{Saran}

Berdasarkan hasil pengujian yang telah dilakukan maka penulis memberikan saran atau masukan kepada Radio Republik Indonesia Pekanbaru khususnya dan untuk perusahaan lain pada umumnya guna meningkatkan kinerja karyawan.

a. Motivasi yang terjadi didalam lingkungan perusahaan dapat ditingkatkan dan diperbaiki dengan cara memperhatikan lebih dalam lagi akan kesejahteraan dan kemakmuran karyawan. Atasan sebagai pimpinan hendaknya memperhatikan kebutuhan karyawan dan apa saja faktor-faktor yang dapat meningkatkan kinerja karyawan salah satunya dengan motivasi yang baik.

b. Manajer ataupun pimpinan tertinggi hendaknya lebih bijaksana lagi dalam menjalankan tugas-tugasnya sebagai pimpinan dengan memperhatikan kebijakan-kebijakan yang telah ditetapkan. Pemimpin merupakan orang yang berperan penting dalam meningkatkan kinerja karyawan salah satunya dengan gaya kepemimpinannya. Pemimpin harus bisa menyesuaikan gaya kepemimpinan yang sesuai sehingga para bawahan merasa nyaman dan situasi kerja menjadi kondusif sehingga tujuan-tujuan dari perusahaan dapat tercapai dengan baik dan dalam diri karyawan sendiri akan timbul rasa loyalitas. 


\section{DAFTAR PUSTAKA}

Ancok, Djamaludin, 2012, Psikologi Kepemimpinan \& Inovasi, Penerbit Erlangga, Jakarta Arikunto, 2006, Manajemen Penelitian, Cetakan ketujuh, Rineke Cipta,Jakarta.

Cahyani, Ati, Strategi dan Kebijakan Manajemen Sumber Daya Manusia, PT. Indeks, Jakarta, 2009

Djoko, Purwanto, M.B.A. 2006. Komunikasi Bisnis. Penerbit Erlangga : Jakarta

Ghozali, Imam, 2006, Aplikasi Analisis Multivariate Dengan Program SPSS,Badan Penerbit Universitas Diponegoro, Semarang

Gomes, M.Si., DR. Faustino Cardoso, 2003, Manajemen Sumber Daya Manusia, Penerbit Andi, Yogyakarta,

Mangkunegara, Anwar, AA, 2005. Perilaku Konsumen. Bandung : Repika Aditama

Marnis, SE.,MS., 2008. Pengantar Manajemen. UNRI Press : Pekanbaru

Nurmansyah, SR.,MM.,2010,Manajemen Sumber Daya Manusia Strategik. Penerbit : Unilak Press

Nurmansyah, SR.,MM.,2016, Perilaku Organisasi. Penerbit : Unilak Press

Kaltim dan wiliyawati,Cucu, 2016, Pengaruh Gaya Kepemimpinan Transaksional Dan Motivasi Terhadap Karyawan Studi Pada Merlynn Park Hotel Jakarta Pusat

Siregar, Syofian, 2013, Statistik Parametik Untuk Penelitian Kuantitatif,Bumi Aksara, Cetakan Ketiga Belas, Jakarta.

Setiawan,Eko Yudhi,2015, Pengaruh Gaya Kepemimpinan Transformasional dan Transaksional Terhadap Kinerja Karyawan PT. ISS Indonesia diRumah Sakit National Surabaya

NovitaSari,Putri dan Satriyo,Budhi,2016, Pengaruh Gaya KepemimpinanTransformasionaldan Motivasi Kerja terhadap Kinerja Karyawan

Wibisono, Dermawan, 2006, Manajemen Kinerja Konsep, Desain, dan Teknik Meningkatkan Daya Saing Perusahaan. Penerbit Erlangga : Jakarta Waluyo, Minto, 2009, Psikologi Teknik Industri. Penerbit Graha Ilmu: Yogyakarta. 